\title{
Pendidikan berkelanjutan nonformal bagi kepala ruangan di rumah sakit $\mathrm{X}$ di Jakarta
}

\author{
Eti Masiyati ${ }^{*}$, Hanny Handiyani², Nurdiana ${ }^{3}$ \\ 1Program Studi Magister Kepemimpinan dan Manajemen Keperawatan, Fakultas IImu Keperawatan \\ Universitas Indonesia. *Email: masiyatieti77@gmail.com \\ ${ }^{2}$ Fakultas IImu Keperawatan Universitas Indonesia \\ ${ }^{3}$ Bidang Keperawatan RSUPN Dr. Cipto Mangunkusumo, Jakarta
}

\section{Abstract \\ Continuing nurse education among head nurses as a factor of health care quality at hospital X in Jakarta}

Background: The head of the room as a line manager nurse plays an important role in the Health and Nursing Service which is rapidly changing. The head of the room in carrying out his role and function is inseparable from the management process, including applying attention to material resources and human resources of nursing, so the head of the room must have supporting competencies in carrying out their duties.

Purpose: Data obtained through interviews, observations, Focus Group Discussion (FGD) and surveys in the form of questionnaires. Data analysis is intended to diagnose problems and formulate solutions.

Results: The formulation of the problem obtained is not yet optimal continuing education programs for the head of the room. Problem solving in the form of activities using the action research approach that is by applying curriculum-based training methods that are prepared in accordance with the competency standards of the head of the room. The action research was carried out within 3 months, from October to December 2019. The results of this action research showed an increase in knowledge from the head of the room. Evaluation through pre and post test about the training material that has been given. The mean score of pre and post test participants increased from an average of 53.88 to 80.36 or an increase of 26.48 points.

Conclusion: The continuing education program for a head nurse has not been realized and in solving problems in the form of activities using the action research approach method has not been optimally implemented and arranged in accordance with the competency standards of the head of the room. It is recommended that the hospital management be able to evaluate nursing resources, especially for each a head nurse and provide opportunities to participate in continuing education and can improve quality patient care according to current technological advances.

\section{Keywords: Continuing education; Nurse manager; Competence, Head Nurse; Training}

Pendahuluan: Kepala ruangan sebagai perawat manajer lini berperan penting dalam Pelayanan Kesehatan dan Keperawatan yang sangat cepat mengalami perubahan. Kepala ruangan dalam menjalankan peran dan fungsinya tidak terlepas dari proses manajemen, termasuk menerapkan perhatian kepada sumber daya material maupun sumber daya manusia keperawatan, sehingga kepala ruangan harus memiliki kompetensi yang mendukung dalam melaksanakan tugasnya.

Tujuan: Mengidentifikasi penerapan fungsi manajemen sumber daya manusia di bagian keperawatan Metode: Data diperoleh melalui wawancara, observasi, Focus Group Discussion (FGD) dan Survei dalam bentuk kuesioner. Analisis data lebih ditujukan untuk mendiagnosa masalah dan merumuskan metode pemecahannya.

Hasil: Belum optimalnya program pendidikan berkelanjutan bagi kepala ruangan. Penyelesaian masalah berupa Kegiatan dengan menggunakan metode pendekatan action research yaitu dengan menerapkan metode pelatihan berbasis kurikulum yang disusun sesuai dengan standar kompetensi kepala ruangan. Action research ini dilaksanakan dalam waktu 3 bulan yaitu pada bulan Oktober sampai Desember 2019. Hasil dari action research ini menunjukkan peningkatan pengetahuan dari kepala ruangan. Evaluasi melalui pre dan post test tentang materi pelatihan yang sudah diberikan. Nilai rata-rata pre dan post test peserta meningkat dari rata-rata 53.88 menjadi 80.36 atau meningkat 26.48 poin.

Simpulan: Program pendidikan berkelanjutan bagi kepala ruangan belum terealisasi dan dalam penyelesaian masalah berupa kegiatan dengan menggunakan metode pendekatan action research belum optimal diterapkan dan disusun sesuai dengan standar kompetensi kepala ruangan. Disarankan kepada Manajemen rumah sakit supaya dapat mengevaluasi sumber daya keperawatan khususnya pada setiap kepala ruangan dan memberikan kesempatan untuk mengikuti pendidikan berkelanjutan dan dapat meningkatkan pelayanan pasien yang berkualitas sesuai kemajuan teknologi saat ini.

Kata Kunci: Pendidikan berkelanjutan; Kompetensi; Perawat manajer; Pelatihan; Kepala ruangan 


\section{PENDAHULUAN}

Pendidikaan berkelanjutan perawat manajer sangat penting dalam Pelayanan kesehatan dan Keperawatan yang sangat cepat mengalami perubahan. Lingkungan kesehatan dan pelayanan keperawatan mengalami perubahan yang cepat dan perawat berperan penting dalam menyediakan kualitas dan layanan yang aman bagi pasien dalam lingkungan yang terus berubah (Amerika Organisasi perawat Eksekutif (AONE) 2015; Huston, 2013). Pendidikan berkelanjutan bagi perawat manajer mencakup pelaksanaan peran dan fungsi dalam mengelola sumber daya SDM keperawatan, lingkungan, asuhan dan pelayanan keperawatan. Perawat manajer harus meningkatkan kemampuan manajemen dan keterampilan kepemimpinan agar berhasil memenuhi peran vital ini (Waxman et al, 2017; Zulkarnain, 2019; Zendrato, \& Hariyati, 2018).

Perawat manajer yang paling dekat langsung dengan staf keperawatan adalah kepala ruangan. Kepala ruangan sebagai Perawat manajer lini harus memiliki kompetensi yang handal dan sesuai kebutuhan layanan keperawatan. Kompetensi utama kepala ruangan adalah menjalankan peran manajerial yaitu interpersonal roles, informational roles, dan decisional roles serta melaksanakan fungsi manajemen dari mulai planning, organizing, staffing, actuating dan controlling dengan ditunjang beberapa kompetensi diantaranya komunikasi dan manajemen relasi, pengetahuan tentang lingkungan perawatan kesehatan, kepemimpinan, profesionalisme, keterampilan dan prinsip bisnis (Marquis, \& Huston, 2017).

Kebijakan yang mendukung pendidikan berkelanjutan bagi perawat didalam undangundang no 36 tenaga kesehatah tahun 2014 pada pasal 30 ayat 1 dan 2 yaitu pengembangan tenaga kesehatan diarahkan untuk meningkatkan mutu dan karir tenaga kesehatan melalui pendidikan dan pelatihan serta kesinambungan dalam menjalankan praktik. Selain itu pada Standar Kualifikasi Pendidikan Staf (KPS) 8 Komisi Akreditasi Rumah Sakit (KARS) (2012) menyatakan setiap staf memperoleh pendidikan dan pelatihan berkelanjutan, maupun yang lain untuk menjaga atau meningkatkan keterampilan dan pengetahuannya, dan rumah sakit menyediakan fasilitas, waktu untuk pendidikan dan pelatihan staf. Kebijakan tersebut menjadi dasar diperlukannya pendidikan berkelanjutan bagi kepala ruangan untuk meningkatkan kemampuan agar optimal dalam melaksanakan tugas-tugasnya (Puspitaningrum, \& Hartiti, 2017).

Kepala ruangan sebagai manajer lini dituntut selalu meningkatkan kemampuannya agar dapat memimpin dan mengarahkan staf yang berada dalam rentang kendalinya. Seorang pemimpin adalah satu atau lebih orang yang memilih, memperlengkapi, melatih, dan mempengaruhi satu atau lebih pengikut yang memiliki beragam bakat, kemampuan, dan keterampilan dan memfokuskan pengikutnya kepada misi dan tujuan organisasi yang menyebabkan pengikut untuk secara sukarela dan antusias mengeluarkan energi spiritual, emosional, dan fisik dalam upaya terkoordinasi bersama untuk mencapai misi dan tujuan organisasi (Gandolfi, \& Stone, 2018). Kemampuan untuk menjadi pemimpin yang efektif dalam suatu organisasi membutuhkan keterampilan yang terkait dengan kolaborasi, keragaman, pemberdayaan dan tujuan etis. Pemimpin sering digambarkan kuat, berpengaruh, karismatik, dinamis, inovatif, pintar, otokratis, inovatif, dan cerdas (Curtis et al. 2011). Salah satu upaya untuk meningkatkan kompetensi kepala ruangan yaitu melalui pelatihan manajemen ruang rawat yang diharapkan dapat menambah kemampuan perawat manajer dan menerapkan pengetahuan dan keterampilannya dengan penuh tanggung jawab.

Rumah Sakit $X$ sebagai salah satu rumah sakit pemerintah di Jakarta memiliki 100 orang tenaga keperawatan yang berperan sebagai kepala ruangan diseluruh unit pelayanan rawat inap, rawat jalan, intensive dan emergensi. Bidang Keperawatan memiliki data hasil survei pada bulan September 2019 tentang leadership kepala ruangan yang dimenunjukkan bahwa $61.05 \%$ kepala ruangan merasa sudah memiliki kemampuan leadership, $87.76 \%$ memiliki kemampuan untuk nursing care, $91.85 \%$ memiliki kemampuan komunikasi dan relationship, $80 \%$ memiliki kemampuan monitoring dan evaluasi, 86 $\%$ memiliki kemampuan professional dan ethic, $83.27 \%$ memiliki kemmampuan computer literacy, dan $62.11 \%$ memiliki kemampuan quality control. Data tersebut menunjukkan masih ada persepsi kepala ruangan yang merasa kurang terhadap kemampuan leadership dan quality control yaitu jumlah kepala ruangan yang merasa belum

Eti Masiyati** Program Studi Magister Kepemimpinan dan Manajemen Keperawatan, Fakultas llmu Keperawatan

Universitas Indonesia *Email: masiyatieti77@gmail.com

Hanny Handiyani ${ }^{2}$ Fakultas Ilmu Keperawatan Universitas Indonesia

Nurdiana ${ }^{3}$ Bidang Keperawatan RSUPN Dr. Cipto Mangunkusumo, Jakarta 
memiliki kemampuan leadership 39\% dan quality control $38 \%$. Leadership dan quality control merupakan bagian dari standar kompetensi yang harus dimiliki oleh kepala ruangan. Peningkatan kompetensi kepala ruangan dapat dilakukan melalui pendidikan berkelanjutan nonformal yaitu dalam bentuk pelatihan. Tantangan perawatan klinis dan kepemimpinan dalam keperawatan serta tugas manajemen dapat dipenuhi melalui pendidikan dan pelatihan (Winarti, Dharmana \& Ardani, 2016). Lebih khusus, Croft, et al (2018) menyarankan bahwa keterampilan kepemimpinan dapat maju melalui leadership program, lokakarya dan seminar pendidikan profesional.

Pendidian berkelanjutan bagi kepala ruangan sebagai pimpinan di unit pelayanan perlu mendapat perhatian dan dukungan dari pimpinan rumah. Kepemimpinan memiliki dampak positif pada kepuasan karyawan dan pasien ( Curtis, de Vries, \& Sheerin, 2011). Pimpinan rumah sakit harus secara terus menerus berupaya menciptakan peningkatan kualitas yang merupakan proses menciptakan lingkungan di mana setiap individu berusaha meningkatkan kualitas (Raines, 2012).

Permasalahan terkait belum optimalnya pengembangan kompetensi perawat manajer merupakan hal penting dalam manajemen keperawatan dan menjadi fokus penulis untuk melakukan kegiatan yang dilakukan bersama Bidang Keperawatan. Tujuan dari kegiatan ini adalah untuk meningkatkan kemampuan atau kompetensi kepala ruangan dalam melaksanakan peran dan fungsinya sebagai perawat manajer sehingga diharapkan dapat mendorong penyempurnaan manajemen keperawatan dalam mengawal kualitas rumah sakit. Kegiatan ini diawali dengan mengidentifikasi kompetensi apa saja yang dibutuhkan oleh kepala ruangan untuk selanjutnya disusun menjadi kurikulum pelatihan yang akan digunakan pada pelatihan pengembangan kompetensi kepala ruangan.

\section{METODE PENELITIAN}

Metode yang digunakan berupa action research, dengan tujuan dapat teridentifikasi masalah-masalah yang dihadapi oleh kepala ruangan dalam melaksanakan peran dan fungsinya sebagai perawat manajer lini, dan menentukan metode pemecahan masalah. Data dalam penelitian ini diperoleh melalui wawancara, observasi dan Focus Group discussion (FGD) antara peneliti dan partisipan dan analisis data lebih ditujukan untuk mendiagnosa masalah dan merumuskan metode pemecahannya mengikuti siklus action research. Action research ini dilaksanakan dalam waktu 3 bulan yaitu pada bulan oktober sampai Desember 2019, dengan Kepala ruangan sebagai partisipan dan mahasiswa residensi sebagai peneliti.

Cara Kerja atau langkah dalam Action research ini terdiri dari lima tahap yang terdiri dari perumusan (identifikasi) masalah, perencanaan tindakan, pelaksanaan tindakan, evaluasi dan refleksi. Tahap pertama adalah pertemuan antara peneliti dan partisipan yang selanjutnya disebut sebagai small group conference, untuk mendiskusikan isu terkait belum optimalnya pendidikan berkelanjutan bagi kepala ruangan. Pada tahap ini akan diidentifikasi kompetensi apa saja yang harus dimiliki oleh kepala ruangan. Tahap kedua adalah merencanakan tindakan untuk penyelesaian masalah. Pada tahap ketiga mengimplementasikan metode yang telah ditentukan bersama antara peneliti dan partisipan. Selanjutnya pada tahap keempat melakukan evaluasi terhadap pelaksanaan metode pendekatan dan bagaimana respon kepala ruangan terhadap kegiatan tersebut. Pada tahap kelima, peneliti dan partisipan melakukan refleksi terhadap semua kegiatan pada tahap-tahap sebelumnya.

\section{HASIL}

Tahap I: Teridentifikasi masalah belum optimalnya program pendidikan berkelanjutan bagi kepala ruangan. Penetapan masalah berdasarkan data yang didapatkan melalui observasi dan wawancara, FGD dan survei. Observasi dan wawancara kepala ruangan di 13 ruangan yang terdiri dari ruang rawat inap, ruang rawat jalan emergency dan intensive. Tujuan dari observasi dan wawancara kepala ruangan adalah untuk mengidentifikasi penerapan fungsi manajemen. Hasil Observasi dan wawancara menunjukkan kepala ruanga belum membuat visi - misi, tujuan ruang rawat (100\%), $38 \%$ kepala ruangan yang sudah membuat perencanaan pengembangan staf (jumlah, pelatihan, pendidikan) secara tertulis, 69\% melakukan investigasi sederhana dari insiden keselamatan pasien, $8 \%$ memiliki jadwal ronde dan diskusi refleksi kasus, $23 \%$ yang memiliki data

Eti Masiyati** Program Studi Magister Kepemimpinan dan Manajemen Keperawatan, Fakultas llmu Keperawatan

Universitas Indonesia *Email: masiyatieti77@gmail.com

Hanny Handiyani ${ }^{2}$ Fakultas Ilmu Keperawatan Universitas Indonesia

Nurdiana ${ }^{3}$ Bidang Keperawatan RSUPN Dr. Cipto Mangunkusumo, Jakarta 
orientasi pegawai baru, dan $46 \%$ memiliki data penanganan komplain. Hasil wawancara terhadap Kepala Bidang Keperawatan menunjukkan kurang optimalnya pengembangan kompetensi perawat manajer. Sudah lama tidak dilakukan pelatihan manajemen untuk kepala ruangan.

Focus Group Discussion (FGD) dilakukan di Bidang Keperawatan yang dikuti oleh 15 orang kepala ruangan. Penjelasan tentangl tujuan dan topik wawancara serta FGD diberikan sebelum kegiatan, dilanjutkan dengan penandatanganan lembar persetujuan sebagai partisipan. Penulis menggunakan panduan berisi pertanyaan yang bersifat terbuka, serta alat perekam menggunakan handphone untuk mendokumentasikan persepsi dan pendapat partisipan. Hasil FGD didapatkan informasi bahwa kepala ruangan menyatakan perlu adanya pelatihan terlebih dahulu terkait kompetensi karu, Perlu mendapatkan orientasi terhadap unit baru dan uraian tugas baru, Perlu sosok bisa menjadi contoh dalam menjalankan peran, Seharusnya informasi jabatan diberitahukan sebelumnya, perlu mendapat pelatihan terlebih dahulu terkait kompetensi kepala ruangan, dan memerlukan bimbingan, coaching, mentoring.

Survei melalui kuisioner dilakukan terhadap Kepala Ruangan dan staf. Perhitungan sampel menggunakan rumus estimasi proporsi untuk menentukan besar sampel minimal (Sastroasmoro \& Ismael, 2014). Jumlah sampel perawat yang terpilih untuk survei adalah 110 responden. Untuk sampel kepala ruangan dan manajer keperawatan akan diambil dengan metode total sampling dengan jumlah yang bersedia menjadi responden sebanyak 74 orang dari seluruh unit. Perawat melakukan pengisian survey melalui google form. Penggunaa google form dipilih mempertimbangkan waktu pengambilan data yang sangat singkat sehingga diharapkan dapat diperoleh data dengan cepat. Kuisioner diadopsi dari beberapa kuesioner yang sudah digunakan dalam penelitian sebelumnya. Kuisioner yang dimodifikasi berisi pernyataan terkait persepsi Kepala Ruangan dan staf perawat dalam penerapan fungsi manajemen. Data dianalisis secara deskriptif untuk menilai persepsi Kepala ruangan dan Staff perawat.

Hasil kuesioner menggambarkan persepsi kepala ruangan ketika mereka menjalani peran barunya sebagai kepala ruangan. $43.71 \%$ kepala ruangan merasa tidak mendapatkan pelatihan tentang kompetensi kepala ruangan, 33.8\% menunjukkan tidak mendapatkan mendapatkan bimbingan melalui metode coaching, $36.5 \%$ juga menyatakan tidak mendapat bimbingan dengan mentoring, dan $31.1 \%$ mengalami stress peran saat menjadi kepala ruangan. Hasil kuesioner sesuai dengan hasil FGD yaitu kepala ruangan mengalami stress peran saat baru menjadi kepala ruangan. (Grafik 1)

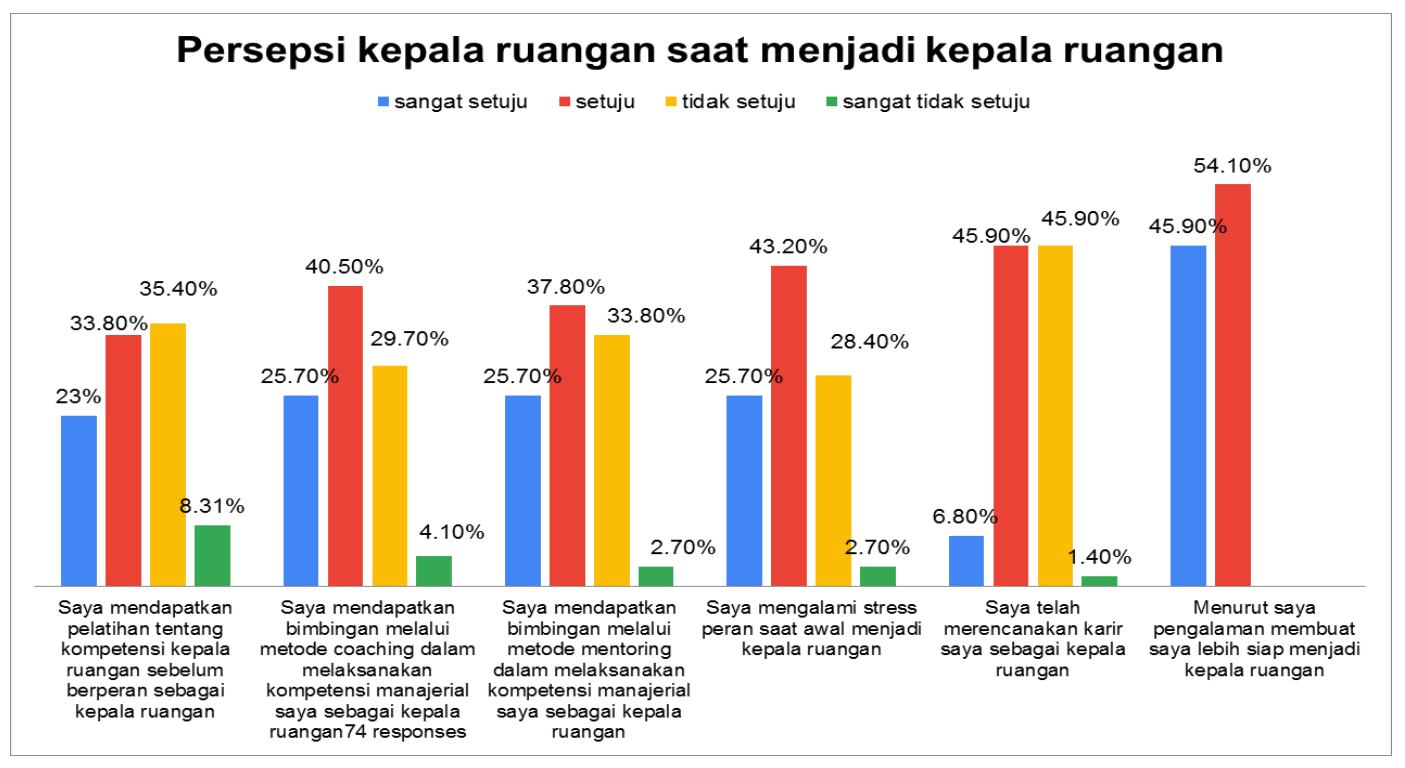

Hasil kuesioner juga menunjukkan bahwa kepala ruangan merasa membutuhkan pelatihan dan bimbingan, dukungan dalam menjalankan perannya. Hal ini ditunjukkan dengan hasil survei dimana $93.2 \%$ tidak setuju bila

Eti Masiyati* Program Studi Magister Kepemimpinan dan Manajemen Keperawatan, Fakultas llmu Keperawatan

Universitas Indonesia *Email: masiyatieti77@gmail.com

Hanny Handiyani ${ }^{2}$ Fakultas Ilmu Keperawatan Universitas Indonesia

Nurdiana ${ }^{3}$ Bidang Keperawatan RSUPN Dr. Cipto Mangunkusumo, Jakarta 
dikat pelatihan dan bimbingan pimpinan terkait kompetensi manajerial tidak banyak manfaatnya dan dapat dipelajari sambil jalan Grafik 2).

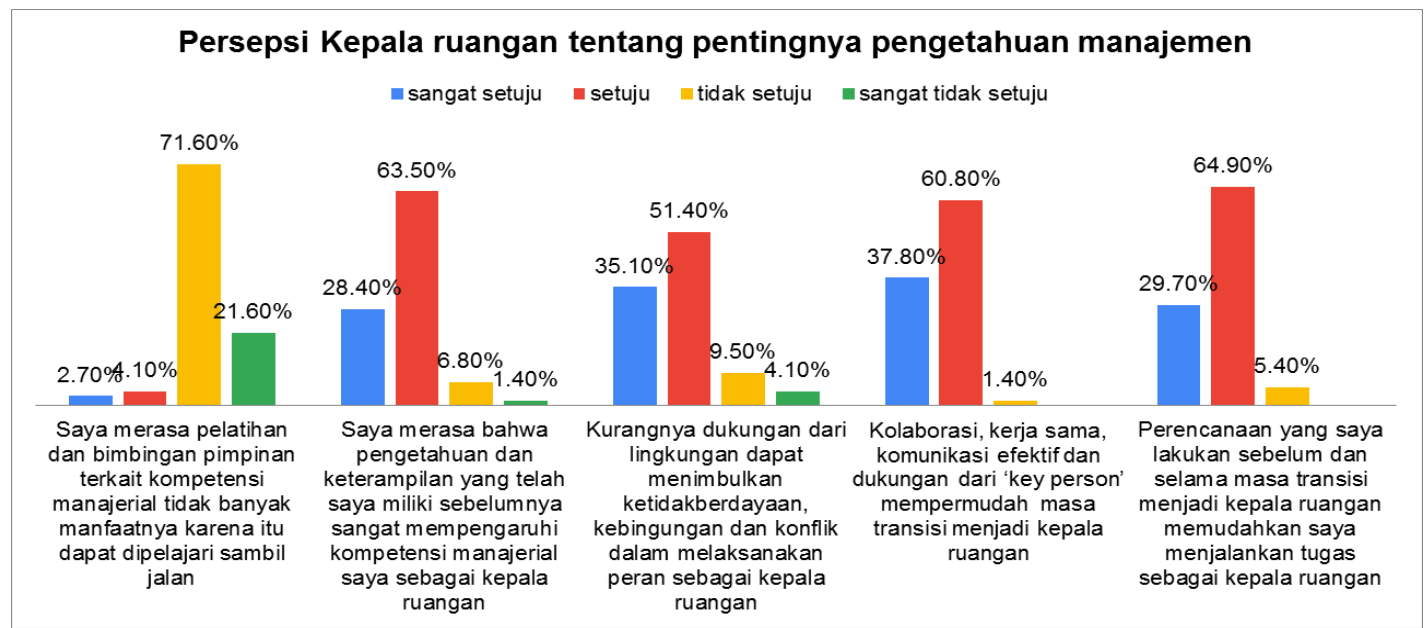

$100 \%$ kepala ruangan mempunyai persepsi bahwa kompetensi manajerial sangat dibutuhkan dan sangat penting dalam organisasi $100 \%$ menyatakan perlu mendapatkan bimbingan dan pelatihan, perlu mengikuti pengembangan professional dan terus meng upgrade kemampuannya (Grafik 3).

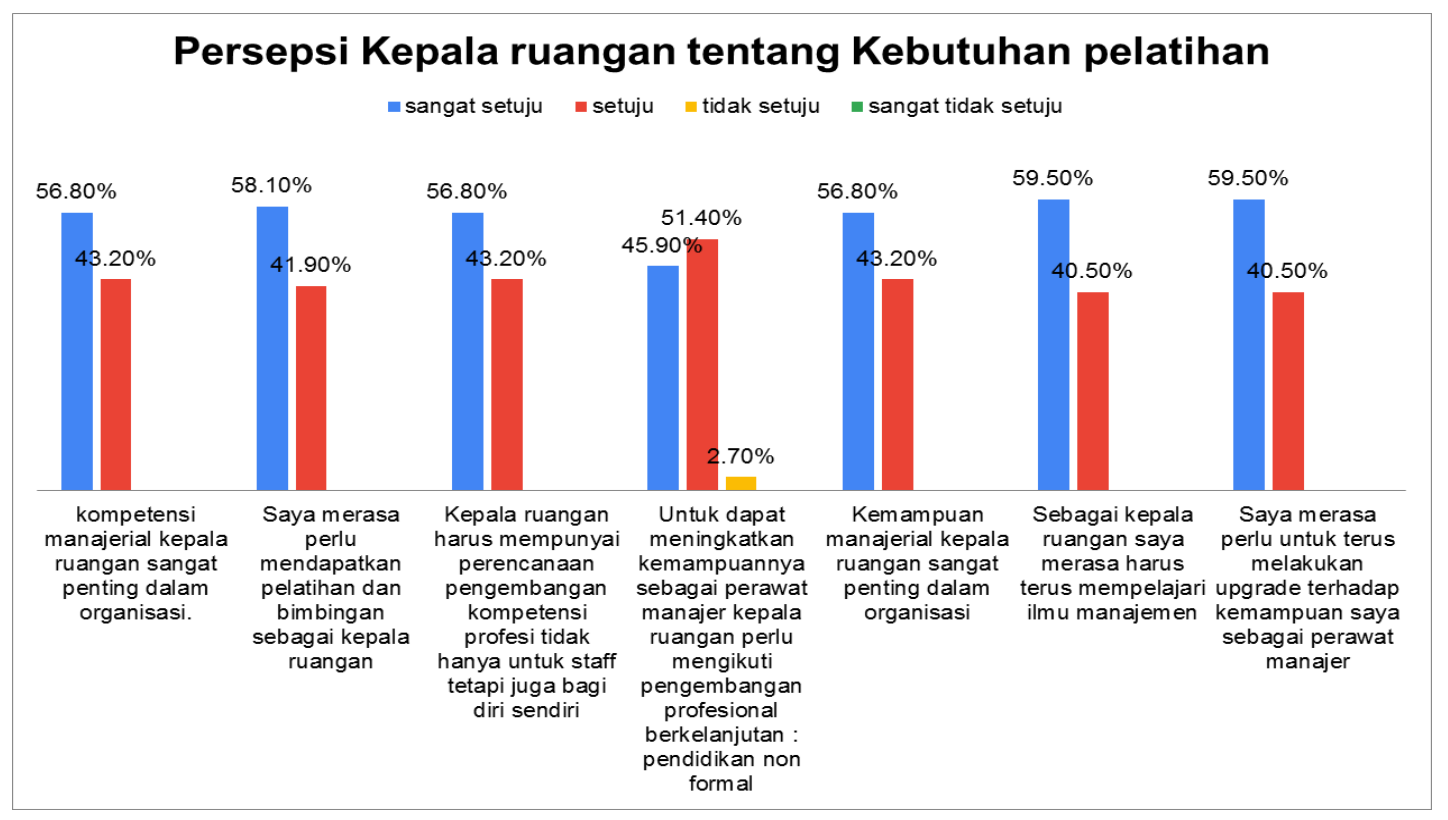

Hasil kuesioner tentang kebutuhan pelatihan juga menunjukan bahwa kepala ruangan membutuhkan ilmu tentang manajemen, manajemen logistik, manajemen konfik, kemampuan Informasi dan tehnologi dan, juga pengelolaan lingkungan kerja yang aman termasuk manajemen risiko Grafik 4)

Eti Masiyati* Program Studi Magister Kepemimpinan dan Manajemen Keperawatan, Fakultas llmu Keperawatan Universitas Indonesia *Email: masiyatieti77@gmail.com

Hanny Handiyani ${ }^{2}$ Fakultas Ilmu Keperawatan Universitas Indonesia

Nurdiana ${ }^{3}$ Bidang Keperawatan RSUPN Dr. Cipto Mangunkusumo, Jakarta 


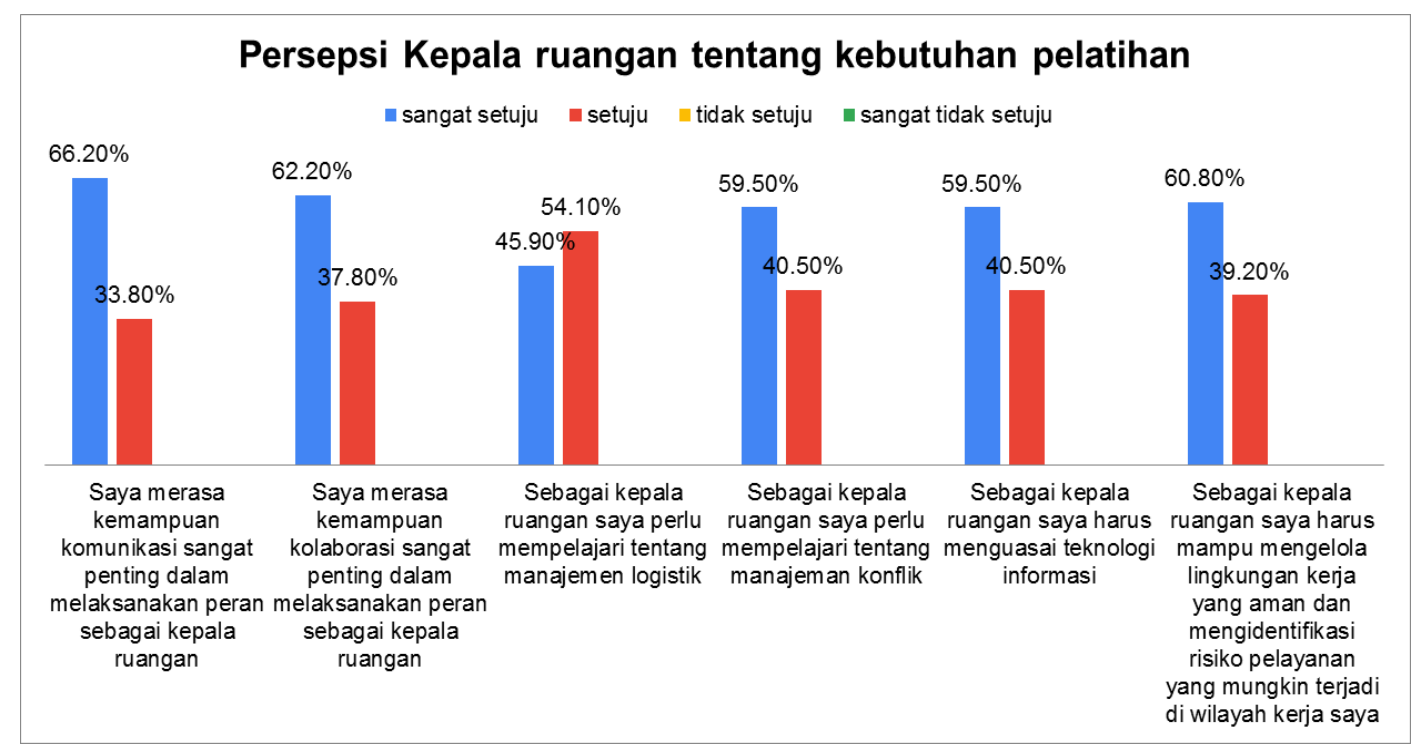

\section{Analisis Masalah}

Berdasarkan analisis data selanjutnya dilakukan penetapan masalah yang diidentifikasi menggunakan diagram fishbone. (gambar 1)

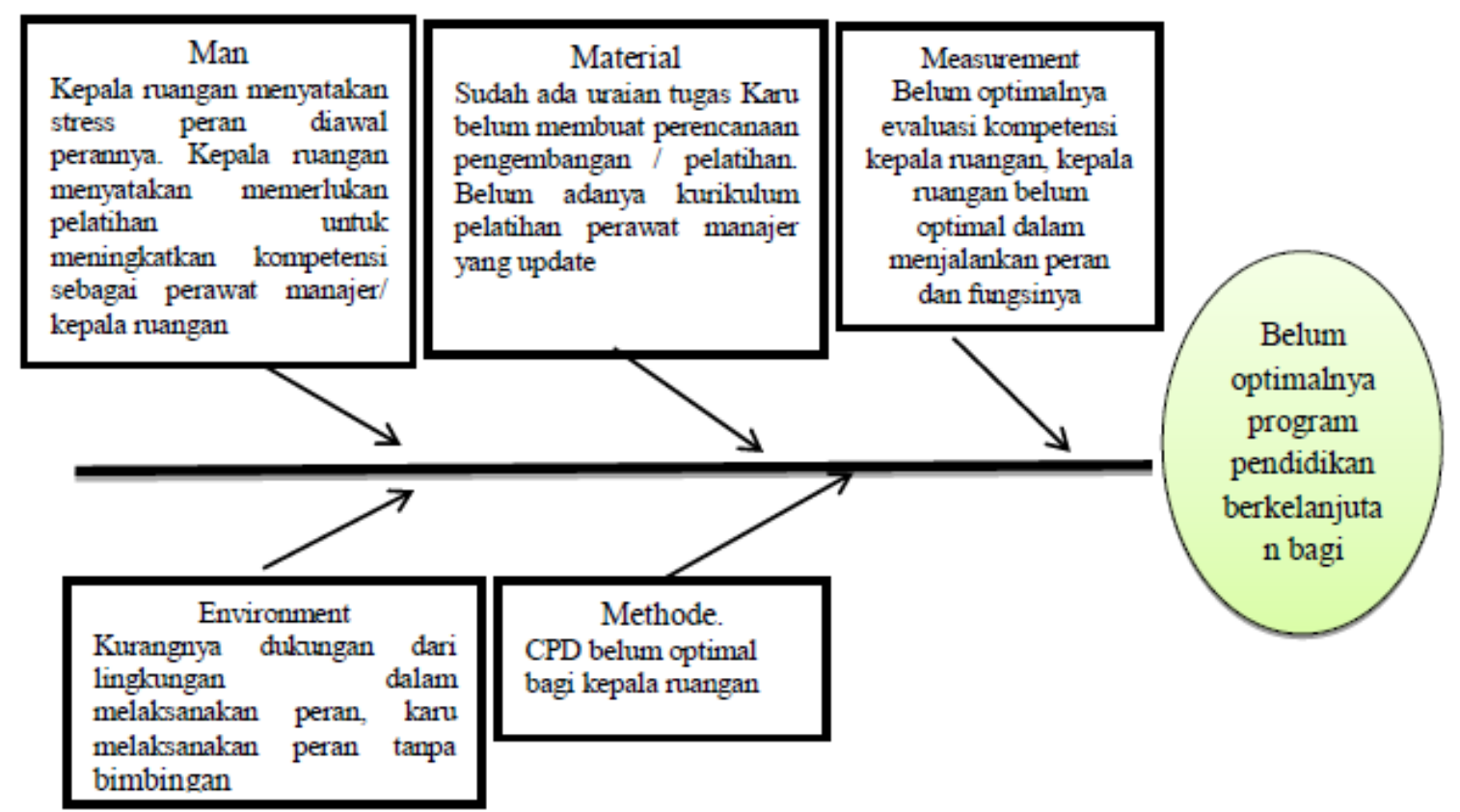

Eti Masiyati* Program Studi Magister Kepemimpinan dan Manajemen Keperawatan, Fakultas llmu Keperawatan Universitas Indonesia *Email: masiyatieti77@gmail.com

Hanny Handiyani ${ }^{2}$ Fakultas Ilmu Keperawatan Universitas Indonesia

Nurdiana ${ }^{3}$ Bidang Keperawatan RSUPN Dr. Cipto Mangunkusumo, Jakarta 
Gambar 1 merupakan analisis masalah dengan pendekatan analisis sebab akibat menggunakan diagram fishbone menunjukkan belum optimalnya program pendidikan berkelanjutan bagi kepala ruangan. Pelatihan manajemen belum terlaksana secara berkesinambungan sehingga kepala ruangan mempunyai persepsi tidak mendapatkan pelatihan dan bimbingan saat menjadi kepala ruangan. Kurikulum pelatihan yang ada juga belum di-update sesuai kebutuhan saat ini, sehingga perlu untuk dibuat kurikulum yang disesuaikan dengan standar kompetensi yang dibutuhkan oleh kepala ruangan. Kurikulum merupakan acuan dalam pelaksanaan pengembangan kompetensi perawat manajer.

\section{Tahap II: Perencanaan tindakan}

Hasil identifikasi masalah menjadi dasar menentukan rencana tindakan penyelesaian. Penyelesaian masalah menggunakan intervensi pelatihan manajemen keperawatan yang ditujukan bagi kepala ruangan yang diawali dengan penyusunan kurikulum pelatihan. Rangkaian kegiatan untuk penyelesaian masalah di buat dalam bentuk Plan of Action (POA) dilakukan bersama Bidang Keperawatan melalui brain storming dan diskusi terarah.

\section{Tahap III: Pelaksanaan Tindakan (Implementasi)}

Pelaksanaan tindakan dengan menggunakan kerangka POSAC yaitu fungsi manajemen keperawatan dari mulai perencanaan, pengorganisasian, ketenagaan, pengarahan, dan pengendalian/ pengontrolan. Pendekatan ini diharapkan dapat secara langsung memberikan solusi masalah pendidian berkelanjutan bagi kepala ruangan oleh Bidang Keperawatan. Pada fungsi perencanaan, implementasi yang dilakukan adalah pengembangan dan penyusunan kurikulum pelatihan manajemen keperawatan yang berisikan Panduan Pelaksanaan pelatihan. Draft kurikulum disusun bersama Bidang Keperawatan dengan melibatkan Komite Keperawatan.

Implementasi fungsi pengorganisasian dan ketenagaan berupa usulan pembentukan tim penyusun kurikulum. Tim penyusun kurikulum terdiri dari:

Penanggung Jawab; Kepala Bidang Keperawatan, Ketua; Koordinator Pengembangan Organisasi dan Profesi, Anggota: Tim Penyusun kurikulum. Koordinator Pengembangan Organisasi dan Profesi adalah manajer level atas yang merupakan pejabat dibawah Kepala Bidang Keperawatan yang bertanggung jawab dalam pengembangan tenaga keperawatan di rumah sakit. Tim penyusun kurikulum merupakan manajer yang memiliki kemampuan dalam Penyusunan materi sesuai dengan kompetensi yang dibutuhkan oleh kepala ruangan. Tim penyusun kurikulum mendapatkan pembagian tugas dalam penyusunan GBPP materi pelatihan.

Implementasi pada fungsi pengarahan, ditindaklanjuti dengan pelaksanaan workshop penyusunan kurikulum pelatihan yang diikuti oleh tim penyusun kurikulum. Draft kurikulum disampaikan dalam sosialisasi dan workshop bersama tim penyusun kurikulum dimana pada kegiatan ini terjadi brainstorming atau tukar pendapat antara anggota tim penyusun kurikulum yang difasilitasi oleh Bidang Keperawatan. Hasil dari workshop tersebut berupa kesepakatan tentang materi yang akan diberikan dalam pelatihan manajemen keperawatan. Adapun materi pelatihan yang ditetapkan dalam kurikulum pelatihan manajemen keperawatan terdiri dari materi dasar, materi inti dan materi penunjang. Materi Dasar yaitu Prinsip etik legal dan budaya, Jenjang karir perawat, Peran perawat manajer dalam menunjang efektivitas dan efisensi pembiayaan rumah sakit. Materi Inti antara lain Peran fungsi dan kompetensi perawat manajer, Manajemen kepemimpinan, Caring perawat manajer, Perencanaan ruang rawat, Pengorganisasian asuhan keperawatan, Pengorganisasian ruang rawat, Staffing, Manajemen konflik, Manajemen logistik keperawatan, Budgeting, Audit keperawatan, Monitoring dan evaluasi dalam asuhan keperawatan, Indikator operasional rumah sakit, Manajemen resiko asuhan keperawatan, Pengelolaan mutu keperawatan dan Penilaian kinerja keperawatan. Adapun materi penunjangnya yaitu Building Learning Commitment (BLC), Anti Korupsi Teknik Presentasi dan Rencana Tindak Lanjut (RTL). Hasil workshop berupa kurikulum pelatihan tersebut kemudian dikonsultasikan dengan pakar yang kemudian mendapat masukan erkait dengan metode pembelajaran yang akan digunakan dalam pelatihanMetode pelatihan dalam bentuk Ceramah, diskusi interaktif, diskusi kasus simulasi dan roleplay. Implementasi fungsi pengarahan (Actuating) selanjutnya adalah

Eti Masiyati** Program Studi Magister Kepemimpinan dan Manajemen Keperawatan, Fakultas llmu Keperawatan

Universitas Indonesia *Email: masiyatieti77@gmail.com

Hanny Handiyani ${ }^{2}$ Fakultas Ilmu Keperawatan Universitas Indonesia

Nurdiana ${ }^{3}$ Bidang Keperawatan RSUPN Dr. Cipto Mangunkusumo, Jakarta 
penerapan kurikulum pada pelatihan manajemen keperawatan yang diikuti oleh seluruh Kepala ruangan dari seluruh unit kerja rawat inap, rawat jalan, intensive dan emergensi. Implementasi fungsi pengendalian, dilakukan dengan melakukan evaluasi terhadap pelaksanaan pelatihan dan peningkatan kompetensi kepala ruangan setelah mengikuti pelatihan melalui post test.

\section{Tahap IV: Evaluasi}

Evaluasi dilakukan pasca pelatihan melalui pre dan post test tentang materi pelatihan yang sudah diberikan. Nilai rata-rata pre dan post test peserta meningkat dari rata-rata 53.88 menjadi 80.36 atau meningkat 26.48 poin (grafik 5 dan 6).

\section{Tahap V: Hasil refleksi}

Partisipan mengungkapkan pengalamannya. persepsi yang baik dari kepala ruangan. Kepala ruangan menyatakan bahwa pelatihan manajemen keperawatan ini sudah lama diharapkan dan sangat bermanfaat, sebaiknya program ini dapat dilaksanakan secara berkesinambungan.

\section{PEMBAHASAN}

Pendidikaan berkelanjutan perawat manajer sangat penting dalam Pelayanan kesehatan dan Keperawatan yang sangat cepat mengalami perubahan. Lingkungan kesehatan dan pelayanan keperawatan mengalami perubahan yang cepat dan perawat berperan penting dalam menyediakan kualitas dan layanan yang aman bagi pasien dalam lingkungan yang terus berubah (Amerika Organisasi perawat Eksekutif (AONE) 2015; Huston, 2013). Pendidikan berkelanjutan bagi kepala ruangan merupakan suatu proses perubahan untuk meningkatkan kompetensi perawat manajer. Proses ini mendapat dukungan penuh dari Bidang Keperawatan dan Kepala ruangan sebagai peserta pelatihan. Kurikulum pelatihan yang disusun bersama, menjadi langkah awal untuk pengembangan kompetensi dengan menyiapkan materi pelatihan yang sesuai dengan standar yang dibutuhkan. Kurikulum pelatihan yang disusun mengacu pada AmericanOrganization of Nurse Executive (AONE) 2015.

Suasana layanan kesehatan yang terus berubah membutuhkan adaptasi terus-menerus, dan kemampuan untuk membangun hubungan dengan tim kesehatan interdisipliner dan untuk bertahan dalam organisasi. Keterampilan yang diperlukan untuk memengaruhi secara positif dan memotivasi anggota tim kerja membutuhkan pemahaman berbagai teori perubahan yang mempengaruhi kemampuan untuk menjadi sukses. Konsep umum yang digunakan untuk menjelaskan proses perubahan biasanya menggambarkan interaksi agen perubahan dengan lingkungan internal dan eksternal. Interaksi agen perubahan dalam layanan kesehatan sistem tergantung pada tiga hambatan: diri, target lingkungan, dan lingkungan eksternal. Teori perubahan Kurt Lewin (1947) menjelaskan tiga fase yang terjadi selama proses perubahan: periode dari unfreezing, periode bergerak, dan periode refreezing (Korniewicz, 2015).

Rumah sakit sebetulnya sudah memiliki program pengembangan bagi tenaga keperawatan dan tenaga lainnya yang dipersyaratkan oleh standar akreditasi rumah sakit, akan tetapi kontinuitas pelaksanaannya yang perlu dipertahankan terutama untuk pendidikan berkelanjutan informal yang terkait dengan kompetensi yang dibutuhkan bagi kepala ruangan. Standar akreditasi Joint Commission International edisi 6 pada bab Staff Qualification and Education (SQE) pasal 8 menyatakan bahwa tiap anggota staff diberikan pelatihan internal serta pendidikan dan pelatihan lain yang berkelanjutan untuk menyokong atau meningkatkan keterampilan dan pengetahuannya (Joint Commission International, 2017). Organisasi perlu mendukung pengembangan kompetensi kepemimpinan kepala ruangan. Program pengembangan kepemimpinan memiliki dampak positif pada pemimpin baru dan pelatihan kepemimpinan memiliki dampak positif pada institusi (Glasman et al, 2012; Sudariani, 2016). Dukungan Pimpinan dan organisasi berperan dan bertanggung jawab dalam mengenali kebutuhan pendidikan dan mendorong aktivitas pendidikan perawat (Coventry et al., 2015; Marquis \& Huston, 2017).

Program pendidikan berkelanjutan bagi informal perlu direncanakan dengan baik. Penentuan materi yang akan diberikan dalam pelatihan juga mengacu pada hasil assessment, kebutuhan dalam pelayanan dan merujuk pada standard kompetensi. Kompetensi utama kepala ruangan adalah menjalankan peran manajerial yaitu interpersonal roles, informational roles, dan decisional roles serta melaksanakan fungsi manajemen dari mulai planning, organizing,

Eti Masiyati* Program Studi Magister Kepemimpinan dan Manajemen Keperawatan, Fakultas llmu Keperawatan

Universitas Indonesia *Email: masiyatieti77@gmail.com

Hanny Handiyani ${ }^{2}$ Fakultas Ilmu Keperawatan Universitas Indonesia

Nurdiana ${ }^{3}$ Bidang Keperawatan RSUPN Dr. Cipto Mangunkusumo, Jakarta 
staffing, actuating dan controlling dengan ditunjang beberapa kompetensi diantaranya komunikasi dan manajemen relasi, pengetahuan tentang lingkungan perawatan kesehatan, kepemimpinan, profesionalisme, keterampilan dan prinsip bisnis (American Organization of Nurse Executives, 2015; Riley, 2009; Atmaja, 2018). Kompetensi tersebut selanjutnya ditetapkan dalam kurikulum pelatihan manajemen keperawatan.

Pelatihan manajemen yang dilaksanakan bertujuan untuk meningkatkan kompetensi kepala ruangan. Peningkatan kemampuan leadership, nursing care, komunikasi dan relationship, kemampuan monitoring dan evaluasi, professional dan etik, kemampuan computer serta kemampuan quality control dapat dilakukan dipenuhi melalui pelatihan yang menerapkan kurikulum pelatihan manajemen yang sudah disusun bersama oleh tim. Kurikulum yang mencakup materi dasar, materi inti dan materi penunjang. Metode pelatihan dilaksanakan dalam bentuk Ceramah, diskusi interaktif, diskusi kasus simulasi dan roleplay, dengan jumlah jam pelatihan sebanyak $46 \mathrm{JPL}$. Penerapan kurikulum yang dilakukan pada pelatihan manajemen keperawatan berdasarkan hasil diskusi bersama pakar dari HPMI (Himpunan Perawat Manajer Indonesia) ternyata belum semua mencakup kompetensi yang dibutuhkan oleh kepala ruangan. Selain itu jumlah jam pelajaran dalam pelatihan juga masih kurang mencukupi. Seharusnya jumlah jam pelajaran yang diberikan adalah $150 \mathrm{JPL}$ sedangkan pada kurikulum yang sudah dibuat dan dilaksanakan pada pelatihan manajemen keperawatan baru $46 \mathrm{JPL}$. Perlu ada penyempurnaan terhadap kurikulum yang sudah disusun. Keikutsertaan kepala ruangan dalam pelatihan manajemen keperawatan menunjukkan motivasi kepala ruangan untuk melakukan peningkatan pengetahuan dan keterampilan secara berkesinambungan. Hal ini juga sesuai dengan teori perubahan Roger yang menyatakan bahwa untuk mengadakan perubahan diperlukan adanya kesadaran untuk berubah dan bahwa untuk mengadakan perubahan harus timbul perasaan suka / minat terhadap perubahan. Timbulnya minat akan mendorong dan menguatkan kesadaran untuk berubah (Marquis \& Huston, 2017).

Perawat manajer merupakan kunci dalam mewujudkan mutu pelayanan yang tinggi, Perawat manajer di setiap level, melaksanakan fungsi manajemen untuk memastikan mutu pelayanan keperawatan dan bertanggung jawab untuk menciptakan lingkungan yang aman dan sehat yang mendukung kinerja tim kesehatan, mendorong pelayanan keperawatan yang efektif dan efisien, serta berkontribusi pada pelayanan yang bermutu terhadap pasien sebagai pelanggan utama (American Organization of Nurse Executives, 2015; Riley, 2009) oleh karena itu seluruh kepala ruangan harus diikutsertakan dalam program pendidikan berkelanjutan, sehingga dapat meningkatkan peran dan fungsinya dalam melakukan pengelolaan pelayanan. Pendampingan, bimbingan, dan mentoring dari manajemen kepada kepala ruangan merupakan hal yang juga dibutuhkan selain pelatihan, sebagai bentuk pengarahan yang dapat menumbuhkan kekuatan dan percaya diri dalam menjalankan peran dan fungsinya sebagai front line manajer.

\section{SIMPULAN}

Program pendidikan berkelanjutan dalam bentuk pelatihan manajemen keperawatan yang ditujukan kepada perawat manajer khusunya kepala ruangan cukup efektif meningkatkan pengetahuan Kepala Ruangan dan membuka wawasan lebih luas tentang standar kompetensi yang dibutuhkan sebagai perawat manajer yang dipersyaratkan akreditasi rumah sakit. Persepsi yang baik dari Kepala Ruangan tentang pentingnya pengembangan kompetensi melalui pelatihan sebagai upaya meningkatkan kemampuan manajerial serta motivasi yang tinggi untuk meningkatkan kualitas serta kemampuan diri menjadi modal awal yang baik untuk melakukan perubahan dan perbaikan dalam menjalankan fungsinya sebagai perawat manajer. Peningkatan kompetensi melalui pelatihan memerlukan dukungan rumah sakit dalam pelaksanaannya. Dukungan dan motivasi yang ditunjukkan pimpinan rumah sakit, komunikasi dan memotivasi untuk melakukan inovasi dan perbaikan sangat mendukung peningkatan kualitas manajemen keperawatan.

\section{SARAN}

Pihak manajemen: Rumah sakit memberikan dukungan penuh dalam program pendidikan berkelanjutan bagi kepala ruangan karena posisi kepala ruangan sebagaimperawat manajer lini

Eti Masiyati** Program Studi Magister Kepemimpinan dan Manajemen Keperawatan, Fakultas llmu Keperawatan

Universitas Indonesia *Email: masiyatieti77@gmail.com

Hanny Handiyani ${ }^{2}$ Fakultas Ilmu Keperawatan Universitas Indonesia

Nurdiana ${ }^{3}$ Bidang Keperawatan RSUPN Dr. Cipto Mangunkusumo, Jakarta 
sangat penting dalam peningkatan kualitas pelayanan.

Pendidikan keperawatan: Kurikulum yang telah disusun dan disepakati hendaknya dilanjutkan oleh rumah sakit untuk ditindaklanjuti dan disempurnakan. Evaluasi dan perbaikan terhadap kurikulum secara periodik agar materi dari pelatihan yang diberikan dapat up to date dan sesuai dengan kebutuhan pengembangan. Evaluasi terhadap kinerja kepala ruangan perlu dilakukan sebagai upaya refreezing dari proses perubahan kemampuan kepala ruangan setelah pelatihan.

\section{DAFTAR PUSTAKA}

American Organization of Nurse Executives (AONE). (2015). AONE Nurse Manager Competencies. Chicago, IL: Author.

Atmaja, B. P. (2018). Pelaksanaan case management oleh kepala ruang di RSUD Banjarmasin. Jurnal Kesehatan STIKES Darul Azhar Batulicin, 5(1).

Coventry, P., Lovell, K., Dickens, C., Bower, P., Chew-Graham, C., McElvenny, D., \& Baguley, C. (2015). Integrated primary care for patients with mental and physical multimorbidity: cluster randomised controlled trial of collaborative care for patients with depression comorbid with diabetes or cardiovascular disease. bmj, 350.

Croft, B., Simon-Rusinowitz, L., Loughlin, D. M., \& Mahoney, K. J. (2018). Mental health leadership perspectives on self-direction. Social Work in Mental Health, 16(4), 381-399.

Curtis, E. A., de Vries, J., \& Sheerin, F. K. (2011). Developing leadership in nursing: exploring core factors. British Journal of Nursing, 20(5), 306-309.

Curtis, E. A., Sheerin, F. K., \& de Vries, J. (2011). Developing leadership in nursing: the impact of education and training. British Journal of Nursing, 20(6), 344-352.
Gandolfi, F., \& Stone, S. (2018). Leadership, leadership styles, and servant leadership. Journal of Management Research, 18(4), 261-269.

Glasman, N., Cibulka, J., \& Ashby, D. (2012). Program self-evaluation for continuous improvement. Educational Administration Quarterly, 38(2), 257-288.

Huston, T. L. (Ed.). (2013). Foundations of interpersonal attraction. Elsevier.

Korniewicz, D. (2015). Nursing Leadership and Management.

Marquis, B. L., \& Huston, C. J. (2017). Leadership roles and management functions in nursing: Theory and application. In Leadership Roles and Management Functions in Nursing: Theory and Application (8th ed.). https://doi.org/10.1097/00006216

Puspitaningrum, I., \& Hartiti, T. (2017). Peningkatan kualitas personal Dan profesional perawat melalui Pengembangan keprofesian Berkelanjutan (PKB). Deepublish.

Raines, D. A. (2012). Quality Improvement, Evidence-Based Practice, and Nursing Research... Oh My!. Neonatal Network, 31(4), 262-264.

Riley, V. (2009). AONE's Transforming Care at the Bedside Dissemination Initiative Update. Nurse Leader, 7(4), 15.

Sastroasmoro, S., \& Ismael, S. (2014). Dasardasar metodologi penelitian klinis. Jakarta: sagung seto, 55.

Sudariani, P. W. (2016). Pengembangan Model Kompetensi Kepemimpinan Kepala Ruang Sebagai Upaya Peningkatan Motivasi Dan Kinerja Perawat Pelaksana (Studi Kasus: Rumah Sakit Umum Daerah Kota Mataram, Nusa Tenggara Barat). Jurnal Ners, 11(2), 176185.

Eti Masiyati* Program Studi Magister Kepemimpinan dan Manajemen Keperawatan, Fakultas Ilmu Keperawatan

Universitas Indonesia *Email: masiyatieti77@gmail.com

Hanny Handiyani ${ }^{2}$ Fakultas Ilmu Keperawatan Universitas Indonesia

Nurdiana ${ }^{3}$ Bidang Keperawatan RSUPN Dr. Cipto Mangunkusumo, Jakarta 
Pendidikan berkelanjutan nonformal bagi kepala ruangan di rumah sakit X di Jakarta

Waxman, K. T., Roussel, L., Herrin-Griffith, D., \& D'Alfonso, J. (2017). The AONE nurse executive competencies: 12 years later. Nurse Leader, 15(2), 120-126.

Winarti, R., Dharmana, E., \& Ardani, H. (2016). Pengaruh penerapan asuhan keperawatan spiritual terhadap kepuasan pasien di Rumah Sakit Islam Sultan Agung Semarang (Doctoral dissertation, Diponegoro University).
Zendrato, M. V., \& Hariyati, R. T. S. (2018). Optimalisasi Pengelolaan Asuhan Keperawatan di Instalasi Rawat Jalan Rumah Sakit X. Jurnal Persatuan Perawat Nasional Indonesia (JPPNI), 2(2), 85-99.

Zulkarnain, Z. (2019). Analisis Pelaksanaan Fungsi Manajemen Pengarahan Kepala Ruangan Dengan Kinerja Perawat Dalam Menerapakan Asuhan Keperawatan Di Ruang Rawat Inap RSUD Bima. JISIP (Jurnal IImu Sosial dan Pendidikan), 1(2).

Eti Masiyati* Program Studi Magister Kepemimpinan dan Manajemen Keperawatan, Fakultas llmu Keperawatan Universitas Indonesia *Email: masiyatieti77@gmail.com

Hanny Handiyani ${ }^{2}$ Fakultas Ilmu Keperawatan Universitas Indonesia

Nurdiana ${ }^{3}$ Bidang Keperawatan RSUPN Dr. Cipto Mangunkusumo, Jakarta 